\title{
KAJIAN IMPLEMENTASI MANAJEMEN RISIKO UNTUK MENJAMIN KEAMANAN PANGAN PADA MASA PANDEMI COVID-19 DENGAN METODE HOUSE OF RISK (STUDI KASUS: BOYS CAKE \& BAKERY SUKOHARJO)
}

\author{
Implementation Study of Risk Management for Food Safety Assurance \\ during COVID-19 Pandemic Using House of Risk Method \\ (A Case Study: Boys Cake \& Bakery Sukoharjo)
}

\author{
Tri Putra Kurnia Ramadhan 1 , Fakhrina Fahma² dan Wahyudi Sutopo ${ }^{3}$ \\ 1,2,3Program Studi Teknik Industri, Fakultas Teknik, Universitas Sebelas Maret, \\ Jl. Ir. Sutami No. 36A, Jebres, Surakarta, Jawa Tengah, Indonesia \\ E-mail: tpkramadhan@gmail.com
}

\begin{abstract}
Abstrak
Saat ini, dunia sedang menghadapi pandemi COVID-19 yang merupakan bencana kemanusiaan terhebat sejak perang dunia ke-II. Korban COVID-19 semakin hari semakin bertambah dan penyebarannya semakin meluas. Penyebaran COVID-19 tidak hanya mengancam kesehatan manusia, namun juga aspek sosial dan ekonomi kehidupan manusia. Beberapa industri terancam tidak beroperasi, namun industri pangan tetap beroperasi untuk memenuhi kebutuhan pokok manusia. Dalam kondisi tersebut, Badan Pengawas Obat dan Makanan (BPOM) menerbitkan Pedoman Produksi dan Distribusi Pangan Olahan pada Masa Status Darurat Kesehatan COVID-19. Pedoman ini menjadi panduan bagi pelaku usaha pangan dalam berproduksi dan mendistribusikan pangan olahan dengan menerapkan upaya pencegahan risiko penyebaran COVID-19. Tulisan ini bertujuan untuk melakukan mitigasi risiko keamanan pangan di Boys Cake \& Bakery selama masa pandemi COVID-19. Boys Cake \& Bakery merupakan industri roti dan kue yang tetap menjalankan bisnisnya ditengah pandemi ini. Meskipun demikian, selama pandemi ini pendapatan Boys Cake \& Bakery mengalami penurunan dikarenakan kekhawatiran masyarakat terkait keamanan dan mutu pangannya. Untuk itu, pihak Boys Cake \& Bakery perlu mengidentifikasi dan mengelola risiko untuk menjamin keamanan \& mutu produknya di masa pandemi ini. Implementasi pengelolalan (manajemen) risiko mengacu pada SNI ISO 31000 dengan menggunakan metode House of Risk (HOR). Hasil kajian/penelitian menunjukkan terdapat 24 kejadian risiko yang ditemukan dan 32 penyebab risiko teridentifikasi. Berdasarkan prinsip pareto, teridentifikasi sepuluh penyebab risiko yang dominan serta didapatkan 19 tindakan pengendalian yang dirancang untuk melakukan penanganan risiko pada Boys Cake \& Bakery di masa pandemi Covid-19.
\end{abstract}

Kata kunci: manajemen risiko, keamanan pangan, pedoman BPOM, House of Risk

\section{Abstract}

Currently, the world is facing Pandemic COVID-19, which is the greatest catasthropy since the World War II. Number of people infected by the virus is rising and area coverage is expanding. COVID-19 Pandemic is not only threatening human life, but also social and economy aspects of human's life. Some industries are not operated except food industries for primary needs. Accordingly, Food and Medicine Monitoring Agency (Badan Pengawas Obat dan Makanan, BPOM) provided Guidelines for the Production and Distribution of Processed Food during the Covid-19 Health Emergency Status Period. This guideline is a guide for food business actors in producing and distributing processed food by implementing efforts to prevent the risk of spreading COVID-19. Boys Cake \& Bakery is an industry that continues to run its business during this pandemic. However, during this pandemic the revenue of Boys Cake \& Bakery has decreased due to public concerns regarding food safety and quality. So that, Boys Cake \& Bakery needs to identify and manage the risk in the context of food quality assurance during this Covid-19 pandemic. Implementation of risk management is carried out in accordance with ISO 31000 guidelines using the House of Risk (HOR) method. Results show there are 24 risk events were found and 32 risk agents were identified. Based on the Pareto principle, ten dominant causes of risk were obtained and 19 control measures were designed to handle risks at Boys Cake \& Bakery during the Covid-19 pandemic.

Keywords: risk management, food safety, BPOM guideline, House of Risk. 


\section{PENDAHULUAN}

Saat ini, dunia sedang menghadapi COVID-19 yang merupakan bencana kemanusiaan terbesar setelah perang dunia ke-II. COVID-19 merupakan penyakit yang disebabkan oleh infeksi virus SARS-Cov-2, yang dapat berdampak ringan sampai berat. Virus ini adalah virus baru penyebab penyakit pernafasan yang tidak dapat dilihat dan tidak bisa diketahui pembawanya. Dalam penyebarannya, penyakit ini dapat menyebar melalui tetesan kecil (droplet) dari hidung atau mulut penderita COVID-19 pada saat batuk atau bersin. Seseorang dapat terinfeksi COVID-19 ketika tanpa sengaja menghirup droplet dari penderita tersebut. Selain itu, COVID19 dapat menyebar ketika terdapat seseorang menyentuh benda yang sudah terkontaminasi dengan droplet tersebut lalu orang itu menyentuh mata, hidung atau mulut (segitiga wajah). (Kemenkes, 2020).

Dalam menyikapi kondisi tersebut, World Health Organization (WHO) telah menyatakan COVID-19 sebagai Global Pandemic pada tanggal 11 Maret 2O2O. Sementara itu, Pemerintah RI menetapkan penyebaran COVID19 sebagai bencana nasional. Hal ini dilakukan berdasarkan besarnya danpak yang ditimbulkan. Penyakit ini telah begitu banyak memakan korban jiwa dan menimbulkan kerugian harta benda. Selain itu, penyebaran COVID-19 memiliki cakupan wilayah yang terus meluas. Tidak hanya itu, COVID-19 juga menimbulkan implikasi pada aspek sosial ekonomi yang luas di Indonesia. (Keppres, 2020)

Korban COVID-19 semakin hari semakin bertambah dan penyebarannya semakin meluas. Penyebaran COVID-19 tidak hanya mengancam kesehatan manusia, namun juga aspek sosial dan ekonomi kehidupan manusia. Di sektor sosial, masyarakat takut terhadap penyebaran COVID19. Sementara itu, di sektor ekonomi, beberapa industri terancam tidak beroperasi. (Lukman, 2020). Kondisi ini merupakan implikasi dari adanya anjuran pemerintah untuk terus bekerja dari rumah. Anjuran ini ditujukan untuk melakukan pencegahan penyebaran COVID-19. Hanya saja, tidak semua sektor industri dapat dilaksanakan dari rumah masing-masing pelaku industri. Tentunya, hal ini menjadi dilema tersendiri dimana pencegahan penyebaran COVID-19 harus terus ditingkatkan namun juga sektor industri harus tetap beroperasi guna menopang perekonomian Indonesia (Kemenkes, 2020).

Menyikapi hal ini, pemerintah memperbolehkan beberapa sektor industri untuk tetap beroperasi. Melalui Kementerian Perindustrian, pemerintah terus berupaya mendorong kemudahan serta kelancaran sektor industri beroperasi. Agar industri tetap berjalan dan produktif, selama masa tanggap darurat dampak pandemi COVID-19, Kemenperin mengimbau perusahaan atau industri agar dapat mengantongi surat izin operasional dengan ketentuan memenuhi protokol kesehatan. Arahan Menperin terkait kewajiban perusahaan memiliki surat izin operasional selama masa tanggap darurat pandemi COVID-19 dituangkan dalam surat edaran Menteri Perindustrian Nomor 7 Tahun 2020. Surat edaran ini bertujuan untuk menjamin pelaksanaan operasional bagi industri yang memerlukan keberlanjutan dalam proses produksinya dan perlu diberikan dukungan kemudahan dan fasilitasi kelancaran mobilisasi usahanya sehingga kebutuhan hidup masyarakat dapat terpenuhi di tengah pandemi ini. Tentunya, perusahaan industri harus bertanggungjawab dalam pelaksanaan dan pengawasan kegiatan usahanya (Kemenperin, 2020).

Salah satu sektor yang diperbolehkan untuk tetap beroperasi adalah sektor industri pangan. Industri pangan tetap beroperasi untuk memenuhi kebutuhan pokok manusia. Sektor ini masuk ke dalam infrastruktur penting. Infrastruktur penting ini didefinisikan sebagai sektor dimana sistem dan jaringannya dianggap sangat penting, sehingga apabila keberlangsungannya terganggu akan berdampak buruk pada keamanan, ekonomi nasional, kesehatan atau keselamatan publik nasional, atau kombinasi daripadanya (Hariyadi, 2020). Meskipun demikian, pengoperasian industri pangan tersebut tetap harus mengikuti ketentuanketentuan protokol kesehatan yang berlaku guna mencegah penyebaran COVID-19 dan menjamin keamanan dan mutu pangannya.

Dalam kondisi tersebut, Badan Pengawas Obat dan Makanan menerbitkan Pedoman Produksi dan Distribusi Pangan Olahan pada Masa Status Darurat Kesehatan COVID-19. Pedoman ini menjadi panduan bagi pelaku usaha pangan agar tetap dapat berproduksi dan mendistribusikan pangan olahan dengan menerapkan upaya pencegahan risiko penyebaran COVID-19. Dengan demikian, ketersediaan pangan akan tetap terjaga dengan keamanan dan mutu yang terjamin. Selain itu, pedoman ini juga merupakan perwujudan dalam percepatan penanganan COVID-19 (BPOM, 2020).

Mengingat kebutuhan pangan dan kondisi yang terjadi sekarang ini, diperlukan kajian risiko keamanan pangan pada Boys Cake \& Bakery. Dalam operasional bisnisnya, Boys Cake \& Bakery memiliki banyak risiko pada masa pandemi ini. Potensi-potensi tersebut berasal dari proses bisnisnya yang selalu melibatkan banyak orang secara langsung baik dari proses pengadaan barang, produksi, maupun penjualannya. Kondisi ini tentunya dapat berisiko 
menularkan COVID-19. Di sisi lain, selama pandemi ini omzet Boys Cake \& Bakery juga mengalami penurunan. Hal ini disinyalir sebagai dampak dari kekhawatiran masyarakat terkait keamanan dan mutu pangan selama pandemi ini sehingga pelanggan enggan membeli produk. Untuk itu, diperlukan upaya manajemen risiko keamanan pangan dalam rangka penjaminan mutu pangan dan utamanya guna mencegah COVID-19 terus menyebar. Oleh karena itu, implementasi manajemen risiko keamanan pangan pada masa pandemi COVID-19 ini sangat perlu untuk dilakukan. Tulisan ini bertujuan untuk melakukan mitigasi risiko keamanan pangan di Boys Cake \& Bakery selama masa pandemi COVID-19 dengan pedoman BPOM menggunakan metode House of Risk.

Metode House of Risk telah digunakan dalam beberapa penelitian untuk melakukan penilaian dan pengendalian risiko. Penelitian sebelumnya yang berhubungan dengan pengendalian risiko dan metode House of Risk dilakukan oleh Hidaya, S (2012) yang menganalisis dan melakukan mitigasi risiko supply chain pada pembudidyaan lobster. Pada penelitian tersebut dilakukan di PT. Crayfish Softshell Indonesia. Selain itu Rahmatullah (2016) juga menggunakan pendekatan metode House of Risk untuk melakukan penanganan risiko rantai pasok di salah satu IKM Intip di Surakarta. Berdasarkan latar belakang tersebut, pada penelitian saat ini digunakan pendekatan metode House of Risk untuk melakukan penilaian dan pengendalian risiko keamanan pangan olahan dengan berfokus pada percepatan pencegahan penyebaran COVID-19 di Boys Cake \& Bakery yang disesuaikan dengan pedoman BPOM terkait produksi dan distribusi pangan olahan pada masa pandemi.

\section{TINJAUAN PUSTAKA}

\subsection{Manajemen Risiko}

Berdasarkan Peraturan Menteri Kesehatan No. 25 tahun 2019, manajemen risiko adalah proses yang proaktif dan kontinyu meliputi identifikasi, analisis, evaluasi, pengendalian, informasi komunikasi, pemantauan, dan pelaporan risiko, termasuk berbagai strategi yang dijalankan untuk mengelola risiko dan potensinya.

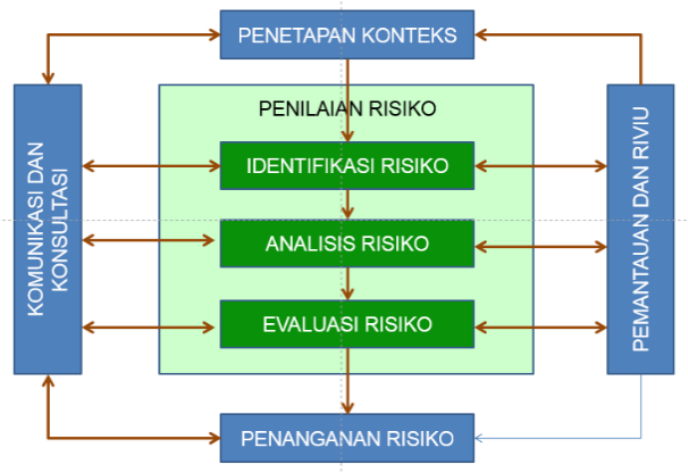

Gambar 1 Proses manajemen risiko

Sumber: BSN (2018)

Sementara itu, tahapan proses manajemen risiko berdasarkan ISO: 31000 dalam (BSN, 2018), adalah sebagai berikut:
a. Komunikasi dan konsultasi
b. Penetapan konteks
c. Penilaian risiko
d. Penanganan risiko
e. Pemantauan dan review

\subsection{Keamanan Pangan}

Permasalahan utama keamanan produk pangan adalah belum terjaminnya keamanan, mutu dan kualitas. (Zazili, 2019). Faktor keamanan merupakan prasyarat bagi pangan yang bermutu. (Hariyadi, 2017). Berdasarkan Peraturan BPOM Nomor 21 Tahun 2019 tentang Program Manajemen Risiko Keamanan Pangan di Industri Pangan, keamanan pangan adalah kondisi dan upaya yang diperlukan untuk mencegah pangan dari kemungkinan cemaran biologis, kimia dan benda lain yang dapat mengganggu, merugikan, dan membahayakan kesehatan manusia serta tidak bertentangan dengan agama, keyakinan, dan budaya masyarakat, sehingga aman dari segi konsumen yang mengkonsumsi maupun produsen yang memproduksi baik secara proses maupun luarannya.

\subsection{Pedoman Produksi dan Distribusi Pangan Olahan Masa Pandemi COVID- 19}

Dalam rantai pangan olahan, perlu diantisipasi pergerakannya serta disinfeksi penggunaan fasilitas higiene guna mencegah penyebaran COVID-19. 


\subsubsection{Sanitasi Pangan}

Menurut BPOM (2020), sanitasi pangan merupakan upaya untuk menciptakan dan mempertahankan kondisi pangan yang sehat dan higienis yang bebas dari bahaya cemaran biologis, kimia, dan benda lain. Dalam rangka memenuhi ketentuan kebijakan pemerintah terkait pencegahan risiko penyebaran COVID-19 serta untuk penjaminan keamanan dan mutu pangan, maka praktik sanitasi pangan berikut harus dilakukan:

a. Penerapan Cara yang Baik

b. Higiene Karyawan

c. Disinfeksi untuk Inaktivasi Virus COVID-19

\subsubsection{Personel}

Menurut BPOM (2020), prinsip higiene dan kesehatan personel dilakukan dengan mengacu pada CPPOB, di mana setiap karyawan harus memantau kesehatan dirinya pribadi secara suka rela. Karyawan yang tidak sehat dilarang masuk bekerja. Pelaku usaha pangan diharapkan mampu menambah fasilitas higiene personel di titik-titik dengan risiko kontak yang tinggi, misalnya penyediaan hand sanitizer di dekat mesin absensi. Apabila perusahaan menyediakan fasilitas transportasi bagi karyawan, fasilitas transportasi yang digunakan juga harus didisinfeksi secara berkala. Praktik terbaik untuk melindungi kesehatan pekerja di fasilitas perusahaan harus diikuti. Pekerja harus mengenakan Alat Pelindung Diri (APD) yang sesuai, yang meliputi pakaian luar pelindung, sarung tangan, sepatu bot, kacamata atau perisai wajah, dan masker; mereka harus sering menjaga kebersihan tangan; dan harus menghindari menyentuh mata, hidung dan mulut dengan tangan yang tidak dicuci.

\subsubsection{Pembatasan Jarak Fisik}

Menurut BPOM (2020), pembatasan jarak secara fisik (physical distancing) merupakan salah satu upaya yang harus dilakukan dalam menekan penyebaran COVID-19, termasuk di fasilitas produksi dan distribusi pangan olahan. Sebagaimana diketahui, pembatasan jarak secara fisik dilakukan dengan menjaga jarak antar personel minimal 1 meter dan menghindari kerumunan. Secara umum, beberapa contoh implementasi pembatasan jarak secara fisik tersebut antara lain sebagai berikut:

a. Mengatur ulang waktu kerja, dapat dilakukan dengan membagi waktu kerja karyawan menjadi beberapa kelompok agar meminimalkan frekuensi pertemuan antara karyawan b. Mengatur pintu keluar dan masuk karyawan sedemikian rupa sehingga karyawan yang berbeda shift kerja tidak bertemu.

c. Memberikan tanda khusus yang ditempatkan di lantai area yang padat karyawan, misalnya area kerja, lift, dan area lain sebagai pembatas jarak antar karyawan

d. Mengatur ulang posisi atau tempat duduk karyawan dengan jarak minimal 1 meter di semua area

\subsubsection{Komunikasi, Informasi, dan Edukasi}

Selain melakukan KIE tentang keamanan dan mutu pangan, pelaku usaha pangan perlu mempunyai tim yang bertugas melakukan KIE mengenai pencegahan penyebaran COVID-19. Tim harus menyiapkan petunjuk dan peringatan mengenai pembatasan kontak fisik, higiene perorangan dan penerapan sanitasi bagi karyawan. Penyampaian petunjuk dan peringatan dilakukan kepada karyawan menggunakan media yang sesuai, antara lain penyampaian secara langsung serta penggunaan leaflet, poster, spanduk, banner, media elektronik, dan media sosial. Tim secara rutin mengulang penyampaian petunjuk dan peringatan, misalnya melalui pengeras suara setiap 2 jam, media elektronik yang ada di area perusahaan setiap 1 jam, dan sebagainya.

\subsubsection{Distribusi dan Ritel}

Sarana distribusi dan ritel pangan mencakup antara lain gudang distributor, alat transportasi, dan media/tempat pengemasan sekunder/tersier serta took penjualan. Selain menerapkan prinsip Cara Distribusi Pangan yang Baik secara konsisten, juga harus dilakukan upaya pencegahan risiko penyebaran COVID-19 pada sarana distribusi diantaranya:

a. Melakukan disinfeksi permukaan benda yang sering disentuh

b. Menjaga higiene personal

c. Melakukan pembatasan jarak fisik

d. Mengupayakan ruang yang cukup sehingga antar konsumen dapat menjaga jarak aman, baik pada saat pemilihan produk maupun pada saat pembayaran

e. Melakukan upaya pencegahan penyebaran COVID-19 dari konsumen

f. Meminimalkan kontak dengan konsumen

\subsection{Metode House of Risk (HOR)}

Menurut Geraldin (2007), Hidaya (2012), Rahmatullah (2016), dan Luthfiani (2019), secara garis besar, tahapan dalam framework perencanaan strategi dengan menggunakan 
bantuan tool HOR, dibagi menjadi dua fase yakni fase identifikasi risiko (risk identification) dan fase penanganan risiko (risk treatment). Adapun tahapan dalam model House of Risk fase pertama (fase identifikasi risiko) adalah identifikasi proses bisnis, identifikasi kejadian risiko (risk event) dan tingkat dampaknya, identifikasi agen penyebab risiko (risk agent) dan peluang kemunculannya serta korelasi pada hubungan kejadian risiko dan penyebab risiko. Output dari fase 1 ini adalah nilai Aggregate Risk Priority (ARP) yang kemudian dapat diketahui penyebab risiko dominan dengan menggunakan prinsip pareto.

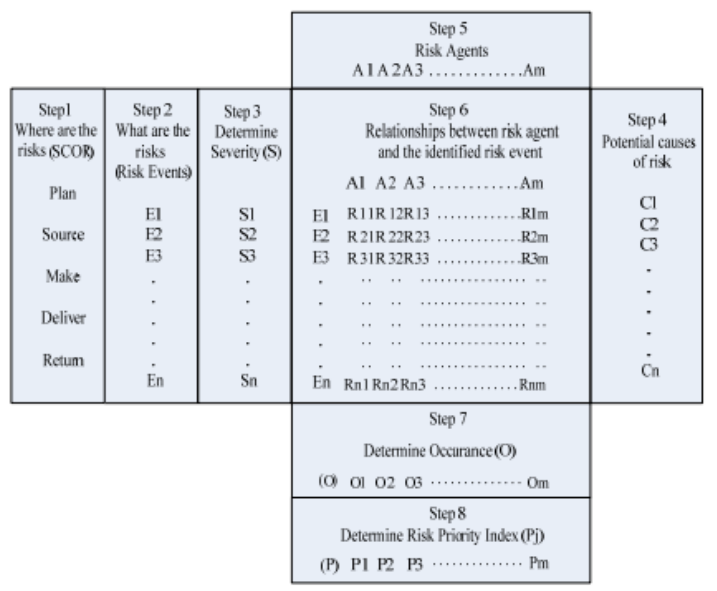

Gambar 2 Tahapan house of risk Sumber: Geraldin (2007)

House of Risk fase 2 berisi tahapan penanganan terhadap penyebab risiko dominan yang terpilih. Tahap ini dimulai dengan melakukan penyusunan rencana tindakan pengendalian. Kemudian, dilakukan identifikasi korelasi antara strategi tindakan pengendalian dengan penyebab risiko dominan, degree of difficulty unutk mendapakan nilai effectiveness to difficulty (ETDk) yang dilakukan dengan focus group dicussion dengan pelaku bisnis.

\section{METODE PENELITIAN}

Penelitian tentang manajemen risiko keamanan pangan masa pandemi COVID-19 di Boys Cake \& Bakery ini terbagi atas lima tahapan. Pertama, melakukan komunikasi dan konsultasi dengan pihak IKM. Kedua, melakukan penetapan konteks untuk memfokuskan ruang lingkup kajian manajemen risiko. Ketiga, mengidentifikasi risiko yang ada di perusahaan. Keempat, merancang penanganan risiko. Kelima, mengevaluasi penanganan risiko yang telah dirancang.

\subsection{Komunikasi dan Konsultasi}

Tahap ini dilakukan untuk menyamakan persepsi dan membantu pemilik risiko dalam memahami risiko yang ada di lingkungan sekitarnya. Komunikasi akan meningkatkan kesadaran dan pemahaman risiko sementara konsultasi mencakup informasi yang diperoleh untuk mendukung pengambilan keputusan. Langkah yang dilakukan pada tahap ini adalah diskusi dengan manajer perusahaan sebagai pengambil keputusan di perusahaan selaku pemilik risiko. Informasi yang diperoleh selanjutnya digunakan untuk tahapan proses selanjutnya.

\subsection{Penetapan Konteks}

Tahap ini bertujuan untuk menetapkan ruang lingkup manajemen risiko yang akan dilakukan. Langkah-langkah yang dilakukan pada tahap ini yaitu menentukan ruang lingkup manajemen risiko, mengidentifikasi peraturan terkait, menetapkan kategori dan kriteria risiko, menetapkan matriks analisis risiko, serta menetapkan level risiko.

\subsection{Identifikasi Risiko}

Tahap ini berisi identifikasi risiko dari proses produksi roti di Boys Cake \& Bakery terkait penularan COVID-19. Data didapatkan dengan membedah proses bisnis perusahaan amatan yang disesuaikan dengan rekomendasi pencegahan penularan Covid-19 yaitu pedoman BPOM terkait produksi dan distribusi pangan olahan masa pandemi. Proses identifikasi dilakukan menggunakan model SCOR (plan, source, make, deliver dan return).

\subsection{Analisis Risiko}

Pada tahap ini dilakukan analisis menggunakan metode House of Risk fase pertama. Berdasarkan proses bisnis yang telah diketahui, dilakukan analisis risiko dengan mengidentifikasi kejadian risiko (risk event) dan tingkat dampaknya (severity), agen penyebab risiko (risk agent) dan peluang kemunculannya (occurance), serta korelasi antara suatu kejadian risiko dengan agen penyebab risiko. Penentuan nilai severity dan occurance ini dilakukan menggunakan kuesioner dengan skala 1-10 yang diisi oleh pakar (expert) sehingga tidak diperlukan uji validitas. Pada penelitian ini dipilih manajer perusahaan selaku pengambil keputusan. Sementara itu, untuk nilai korelasi adalah 1, 3, atau 9 sesuai dengan hubungannya apakah kuat, sedang, atau rendah. Langkah selanjutnya adalah melakukan perhitungan nilai ARP. Nilai 
aggregate risk priority ini didapatkan dengan menghitung menggunakan persamaan $A R P_{j}=$ $O_{j} \sum_{i} S_{i} R_{i j}$

\subsection{Evaluasi Risiko}

Pada tahap ini dilakukan perencanaan tindakan penanganan risiko. Perencanaan dilakukan dengan menggunakan metode House of Risk fase kedua. Terdapat empat langkah dalam melakukan penanangan risiko ini. Langkah pertama adalah menentukan agen risiko yang akan dilakukan penanganan. Berdasarkan hasil perhitungan ARP, ditentukan agen risiko yang dominan. Penentuan agen yang terpilih untuk ditangani ini didasarkan pada prinsip pareto dimana dicari $80 \%$ agen risiko yang dominan mempengaruhi proses bisnis perusahaan. Langkah berikutnya adalah mengidentifikasi tindakan pengendalian sesuai dengan agen risiko yang akan dikendalikan. Identifikasi tindakan pengendalian dilakukan dengan mengacu pedoman BPOM. Selanjutnya, tindakan pengendalian yang telah diidentifikasi dinilai korelasinya dengan agen risiko dan juga tingkat kesulitan penerapannya. Hal ini dilakukan menggunakan kuesioner house of risk fase 2 . Setelah data kuesioner terisi, dilakukan penghitungan nilai tingkat efektivitas masingmasing tindakan pengendalian menggunakan persamaan $T E_{k}=\sum_{j} A R P_{j} E_{j k} \forall k$. Langkah yang terakhir adalah menghitung tingkat efektivitas tindakan pengendalian terhadap kesulitan penerapannya dengan menggunakan persamaan $E T D_{k}=T E_{k} / D_{k}$.

\subsection{Penanganan Risiko}

Pada tahap ini dilakukan perancangan tindakan pengendalian sesuai hasil pada evaluasi risiko yang merupakan hasil dari pengolahan house of risk fase kedua. Hasil pengolahan tersebut kemudian diinformasikan kepada manajer perusahaan selaku pengambil keputusan untuk mrnyusun rencana penanganan risiko keaman pangan di Boys Cake \& Bakery.

\section{HASIL DAN PEMBAHASAN}

Di tengah pandemi Covid-19 ini, Boys Cake \& Bakery berkomitmen untuk menyediakan asupan pangan yang sehat, aman, dan bergizi. Tidak hanya itu, keamanan dan kesehatan pelanggan maupun karyawan kini menjadi perhatiaan utama. Hal ini merupakan wujud penjaminan mutu dan keamanan pangan oleh Boys Cake \& Bakery. Untuk itu, implementasi manajemen risiko keamanan pangan harus dilakukan pada proses bisnis Boys Cake \& Bakery. Dalam implementasinya, komunikasi dan konsultasi dilakukan dengan manajer perusahaan selaku pengambil keputusan untuk mendapatkan pemahaman yang sama.

Sementara itu, pada penetapan konteks dilakukan penetapan ruang lingkup penelitian yang dikaji. Hal ini dimaksudkan untuk memfokuskan penelitian dan permasalahan yang ingin diselesaikan. Peneyelesaian manajemen risiko didasarkan pada pedoman produksi dan distribusi pangan olahan pada masa kedaruratan kesehatan pandemi COVID-19 yang dikeluarkan BPOM. Sementara itu, kriteria dan kategori risiko serta level risiko juga dirinci menggunakan pedoman tersebut. Hal ini kemudian dirinci dengan mengidentifikasi proses bisnis Boys Cake \& Bakery mulai dari perencanaan (plan), pengadaan (source), pembuatan (make), penjualan (delivery), dan pengembalian (return).

Berdasarkan observasi dan wawancara yang dilakukan, didapatkan data proses bisnis pada Boys Cake \& Bakery. Proses bisnis kemudian dipetakan menggunakan model SCOR. Proses bisnis disajikan dalam Tabel 1 .

Tabel 1 Identifikasi proses bisnis

\begin{tabular}{|c|c|}
\hline Aktivitas & Identifikasi Proses Bisnis \\
\hline \multirow{2}{*}{ Plan } & $\begin{array}{l}\text { Merencanakan jenis produk yang } \\
\text { akan diproduksi }\end{array}$ \\
\hline & $\begin{array}{l}\text { Merencanakan jumlah produk } \\
\text { yang akan diproduksi }\end{array}$ \\
\hline \multirow{3}{*}{ Source } & Mengecek ketersediaan bahan \\
\hline & Melakukan pemesanan bahan \\
\hline & Melakukan penyimpanan bahan \\
\hline \multirow{6}{*}{ Make } & Mencampur bahan \\
\hline & Membentuk adonan \\
\hline & Mengembangkan adonan \\
\hline & Memanggang adonan \\
\hline & Mendinginkan produk \\
\hline & Membungkus produk \\
\hline \multirow{3}{*}{ Delivery } & $\begin{array}{l}\text { Mengirim produk ke pelanggan } \\
\text { Menata produk pada display }\end{array}$ \\
\hline & $\begin{array}{l}\text { Melakukan transaksi dengan } \\
\text { pelanggan }\end{array}$ \\
\hline & Mengemas produk yang dibeli \\
\hline Return & Menarik produk yang tidak terjual \\
\hline
\end{tabular}

Setelah itu, dilakukan identifikasi kejadian risiko berdasarkan proses bisnis tersebut. Terdapat 24 kejadian risiko yang teridentifikasi. Rincian kejadian risiko disajikan pada Tabel 2. 
Kajian Implementasi Manajemen Risiko untuk Menjamin Keamanan Pangan pada Masa Pandemi Covid-19 dengan Metode House Of Risk (Studi Kasus: Boys Cake \& Bakery Sukoharjo) (Tri Putra Kurnia Ramadhan, Fakhrina Fahma dan Wahyudi Sutopo)

Tabel 2 Rekapitulasi kejadian risiko.

\begin{tabular}{|c|c|}
\hline Kode & Kejadian Risiko \\
\hline E1 & $\begin{array}{l}\text { Perencanaan jenis produksi } \\
\text { kurang tepat }\end{array}$ \\
\hline E2 & Kehilangan pesanan \\
\hline E3 & Kekurangan bahan baku \\
\hline E4 & $\begin{array}{l}\text { Keterlambatan kedatangan } \\
\text { pasokan bahan baku }\end{array}$ \\
\hline E5 & $\begin{array}{l}\text { Meningkatnya harga bahan } \\
\text { baku dari supplier }\end{array}$ \\
\hline E6 & $\begin{array}{l}\text { Kuantitas bahan baku tidak } \\
\text { sesuai }\end{array}$ \\
\hline E7 & $\begin{array}{l}\text { Kualitas bahan baku tidak } \\
\text { sesuai }\end{array}$ \\
\hline E8 & $\begin{array}{l}\text { Pembelian bahan baku secara } \\
\text { mendadak }\end{array}$ \\
\hline E9 & $\begin{array}{l}\text { Potensi terpapar COVID-19 } \\
\text { saat unloading barang }\end{array}$ \\
\hline E10 & $\begin{array}{l}\text { Produksi berjalan tidak sesuai } \\
\text { target }\end{array}$ \\
\hline E11 & $\begin{array}{l}\text { Potensi terpapar COVID-19 } \\
\text { saat pencampuran bahan }\end{array}$ \\
\hline E12 & $\begin{array}{l}\text { Potensi terpapar COVID-19 } \\
\text { saat pembentukan adonan }\end{array}$ \\
\hline E13 & $\begin{array}{l}\text { Potensi terpapar COVID-19 } \\
\text { saat pengembangan adonan }\end{array}$ \\
\hline E14 & $\begin{array}{l}\text { Potensi terpapar COVID-19 } \\
\text { saat pemanggangan adonan }\end{array}$ \\
\hline E15 & $\begin{array}{l}\text { Potensi terpapar COVID-19 } \\
\text { saat pendinginan roti }\end{array}$ \\
\hline E16 & $\begin{array}{l}\text { Potensi terpapar COVID-19 } \\
\text { saat pengemasan roti }\end{array}$ \\
\hline E17 & $\begin{array}{l}\text { Potensi terpapar COVID-19 } \\
\text { saat pergantian shift kerja }\end{array}$ \\
\hline E18 & $\begin{array}{l}\text { Potensi terpapar COVID-19 } \\
\text { melalui kontak benda }\end{array}$ \\
\hline E19 & $\begin{array}{l}\text { Potensi terpapar COVID-19 } \\
\text { saat pengiriman produk }\end{array}$ \\
\hline E20 & $\begin{array}{l}\text { Potensi terpapar COVID-19 } \\
\text { saat menata roti di display }\end{array}$ \\
\hline E21 & $\begin{array}{l}\text { Potensi terpapar COVID-19 } \\
\text { dari konsumen yang datang }\end{array}$ \\
\hline E22 & $\begin{array}{l}\text { Potensi terpapar COVID-19 } \\
\text { saat proses pembayaran }\end{array}$ \\
\hline E23 & $\begin{array}{l}\text { Pengiriman produk ke } \\
\text { pelanggan terlambat }\end{array}$ \\
\hline E24 & Produk tidak laku/kadaluarsa \\
\hline
\end{tabular}

Dari 24 kejadian risiko tersebut, ditemukan sebanyak 32 penyebab risiko (risk agent) yang memicu. Selanjutnya, dilakukan perhitungan nilai aggregate risk priority (ARP) yang diperoleh berdasarkan tingkat dampak (severity), penyebab risiko, korelasi dan peluang kemunculan dari masing-masing kejadian risiko (occurance). Nilai aggregate risk priority (ARP) ini dihitung menggunakan metode HOR fase pertama. Hasil rekapitulasi penyebab risiko dan nilai aggregate risk priority ARP disajikan dalam Tabel 3.

Tabel 3 Rekapitulasi penyebab risiko.

\begin{tabular}{|c|c|c|}
\hline Kode & Penyebab Risiko & ARP \\
\hline A1 & $\begin{array}{l}\text { Banyak kegiatan yang } \\
\text { tidak boleh } \\
\text { diselenggarakan }\end{array}$ & 165 \\
\hline $\mathrm{A} 2$ & $\begin{array}{l}\text { Selera hidup masyarakat } \\
\text { berubah }\end{array}$ & 108 \\
\hline A3 & Bahan baku langka & 105 \\
\hline A4 & $\begin{array}{l}\text { Pasokan bahan baku } \\
\text { terganggu }\end{array}$ & 60 \\
\hline A5 & $\begin{array}{l}\text { Kemampuan supplier } \\
\text { memenuhi bahan rendah }\end{array}$ & 111 \\
\hline A6 & $\begin{array}{l}\text { Tidak ada alternatif } \\
\text { supplier }\end{array}$ & 27 \\
\hline A7 & $\begin{array}{l}\text { Tidak adanya delivery } \\
\text { safety stock }\end{array}$ & 57 \\
\hline A8 & Supplier salah kirim & 66 \\
\hline A9 & $\begin{array}{l}\text { Proses delivery } \\
\text { terhambat }\end{array}$ & 522 \\
\hline A10 & Kapasitas gudang kecil & 40 \\
\hline A11 & $\begin{array}{l}\text { Gudang tidak memiliki } \\
\text { safety stock }\end{array}$ & 105 \\
\hline A12 & $\begin{array}{l}\text { Adanya pesanan secara } \\
\text { mendadak }\end{array}$ & 161 \\
\hline A13 & $\begin{array}{l}\text { Kurangnya kesadaran } \\
\text { supplier terhadap protokol } \\
\text { kesehatan }\end{array}$ & 900 \\
\hline A14 & $\begin{array}{l}\text { Supplier tidak } \\
\text { menerapkan praktik } \\
\text { hygiene dan kesehatan } \\
\text { yang baik }\end{array}$ & 900 \\
\hline A15 & $\begin{array}{l}\text { Petugas supplier tidak } \\
\text { menggunakan alat } \\
\text { pelindung diri }\end{array}$ & 900 \\
\hline A16 & $\begin{array}{l}\text { Terjadi kontak fisik } \\
\text { dengan supplier }\end{array}$ & 270 \\
\hline A17 & $\begin{array}{l}\text { Petugas supplier tidak } \\
\text { menerapkan physical } \\
\text { distancing }\end{array}$ & 300 \\
\hline A18 & Area produksi terbatas & 50 \\
\hline A19 & $\begin{array}{l}\text { Kurangnya kesadaran } \\
\text { karyawan terhadap } \\
\text { protokol kesehatan }\end{array}$ & 3000 \\
\hline A20 & $\begin{array}{l}\text { Karyawan tidak } \\
\text { menerapkan praktik } \\
\text { hygiene dan kesehatan } \\
\text { yang baik }\end{array}$ & 5400 \\
\hline A21 & $\begin{array}{l}\text { Karyawan tidak } \\
\text { menggunakan alat } \\
\text { pelindung diri }\end{array}$ & 9000 \\
\hline A22 & $\begin{array}{l}\text { Terjadi kontak fisik antar } \\
\text { karyawan }\end{array}$ & 4800 \\
\hline
\end{tabular}




\begin{tabular}{|c|c|c|}
\hline Kode & Penyebab Risiko & ARP \\
\hline A23 & $\begin{array}{l}\text { Karyawan tidak } \\
\text { menerapkan physical } \\
\text { distancing }\end{array}$ & 7200 \\
\hline A24 & $\begin{array}{l}\text { Mobilitas karyawan } \\
\text { terbatas }\end{array}$ & 150 \\
\hline A25 & $\begin{array}{l}\text { Pelanggan tidak } \\
\text { menerapkan praktik } \\
\text { hygiene dan kesehatan } \\
\text { yang baik }\end{array}$ & 600 \\
\hline A26 & $\begin{array}{l}\text { Pelanggan tidak } \\
\text { menerapkan personal } \\
\text { hygiene yang baik }\end{array}$ & 1200 \\
\hline A27 & $\begin{array}{l}\text { Pelanggan tidak } \\
\text { menggunakan APD }\end{array}$ & 1800 \\
\hline A28 & $\begin{array}{l}\text { Terjadi kontak fisik } \\
\text { dengan pelanggan saat } \\
\text { pelayanan }\end{array}$ & 1200 \\
\hline A29 & $\begin{array}{l}\text { Pelanggan tidak } \\
\text { menerapkan physical } \\
\text { distancing }\end{array}$ & 1200 \\
\hline A30 & Area toko yang terbatas & 600 \\
\hline A31 & $\begin{array}{l}\text { Menyentuh permukaan } \\
\text { benda yang terkontaminasi } \\
\text { COVID-19 }\end{array}$ & 3900 \\
\hline A32 & Produk kurang diminati & 90 \\
\hline
\end{tabular}

Dari hasil perhitungan aggregate risk priority (ARP), didapatkan urutan penyebab risiko. Untuk mengetahui penyebab risiko yang dominan, digunakan prinsip pareto. Urutan penyebab risiko dan nilai aggregate risk priority (ARP) disajikan dalam Gambar 3.

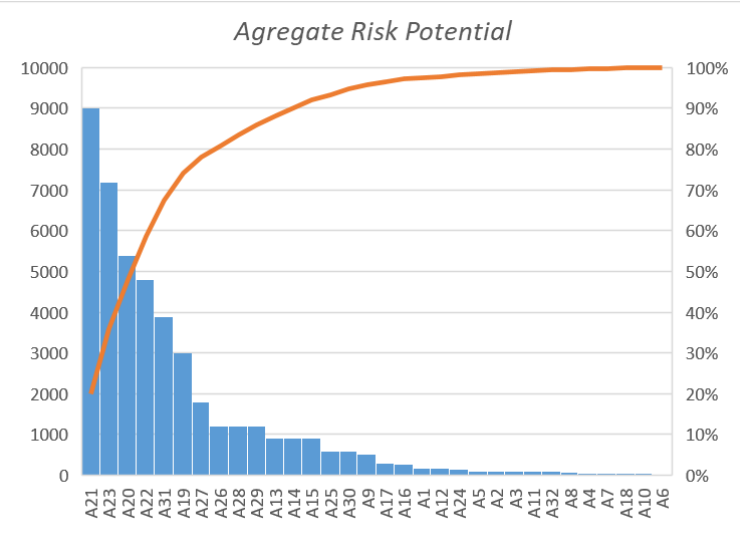

Gambar 3 Diagram pareto ARP

Berdasarkan pengolahan data dari diagram pareto pada Gambar 3, dengan prinsip 80/20 diperoleh sepuluh penyebab risiko yang dominan dari 32 penyebab risiko yang teridentifikasi. Sepuluh penyebab risiko yang dominan tersebut disajikan dalam Tabel 4.
Tabel 4 Rekapitulasi penyebab risiko dominan

\begin{tabular}{|c|c|c|}
\hline Kode & Risk Agent & ARP \\
\hline A21 & $\begin{array}{l}\text { Karyawan tidak } \\
\text { menggunakan alat } \\
\text { pelindung diri }\end{array}$ & 9000 \\
\hline A23 & $\begin{array}{l}\text { Karyawan tidak } \\
\text { menerapkan physical } \\
\text { distancing }\end{array}$ & 7200 \\
\hline A20 & $\begin{array}{l}\text { Karyawan tidak } \\
\text { menerapkan praktik } \\
\text { hygiene dan kesehatan } \\
\text { yang baik }\end{array}$ & 5400 \\
\hline A22 & $\begin{array}{l}\text { Terjadi kontak fisik antar } \\
\text { karyawan }\end{array}$ & 4800 \\
\hline A31 & $\begin{array}{l}\text { Menyentuh permukaan } \\
\text { benda yang terkontaminasi } \\
\text { COVID-19 }\end{array}$ & 3900 \\
\hline A19 & $\begin{array}{l}\text { Kurangnya kesadaran } \\
\text { karyawan terhadap } \\
\text { protokol kesehatan }\end{array}$ & 3000 \\
\hline A27 & $\begin{array}{l}\text { Pelanggan tidak } \\
\text { menggunakan alat } \\
\text { pelindung diri }\end{array}$ & 1800 \\
\hline A26 & $\begin{array}{l}\text { Pelanggan tidak } \\
\text { menerapkan praktik } \\
\text { hygiene dan kesehatan } \\
\text { yang baik }\end{array}$ & 1200 \\
\hline A28 & $\begin{array}{l}\text { Terjadi kontak fisik } \\
\text { dengan pelanggan saat } \\
\text { pelayanan }\end{array}$ & 1200 \\
\hline A29 & $\begin{array}{l}\text { Pelanggan tidak } \\
\text { menerapkan physical } \\
\text { distancing }\end{array}$ & 1200 \\
\hline
\end{tabular}

Kemudian, berdasarkan penyebab risiko dominan yang telah teridentifikasi dilakukan penyusunan rencana tindakan pengendalian menggunakan house of risk fase kedua. Pada tahap ini, peyusunan penanganan risiko dilakukan dengan focus group discussion yang selanjutnya dilakukan pembobotan korelasi dan degree of difficulty dari penerapan tindakan pengendalian tersebut. Hal ini dilakukan untuk memperoleh perhitungan effectiveness to difficulty (ETDk) Rincian tindakan pengendalian dan nilai ETDk disajikan pada Tabel 5.

Tabel 5 Rekapitulasi tindakan pengendalian

\begin{tabular}{clc}
\hline Kode & \multicolumn{1}{c}{ Tindakan Pengendalian } & ETDk \\
\hline PA1 & $\begin{array}{l}\text { Melakukan sosialisasi terkait } \\
\text { pentingnya protokol } \\
\text { kesehatan yang harus } \\
\text { dilakukan }\end{array}$ & 41100 \\
\hline PA2 & $\begin{array}{l}\text { Melakukan monitoring } \\
\text { aktivitas bagi pekerja }\end{array}$ & 20550 \\
\hline PA3 & $\begin{array}{l}\text { Penyediaan fasilitas sanitasi } \\
\text { di area produksi }\end{array}$ & 20100 \\
\hline
\end{tabular}


Kajian Implementasi Manajemen Risiko untuk Menjamin Keamanan Pangan pada Masa Pandemi Covid-19 dengan Metode House Of Risk (Studi Kasus: Boys Cake \& Bakery Sukoharjo) (Tri Putra Kurnia Ramadhan, Fakhrina Fahma dan Wahyudi Sutopo)

\begin{tabular}{|c|c|c|}
\hline Kode & Tindakan Pengendalian & ETDk \\
\hline PA4 & $\begin{array}{l}\text { Pengecekan suhu tubuh bagi } \\
\text { karyawan sebelum bekerja }\end{array}$ & 6400 \\
\hline PA5 & $\begin{array}{l}\text { Mengganti pakaian setelah } \\
\text { tiba di tempat kerja dengan } \\
\text { seragam }\end{array}$ & 12150 \\
\hline PA6 & $\begin{array}{l}\text { Menggunakan masker saat } \\
\text { bekerja }\end{array}$ & 27000 \\
\hline PA7 & $\begin{array}{l}\text { Menggunakan face shield } \\
\text { saat bekerja }\end{array}$ & 27000 \\
\hline PA8 & $\begin{array}{l}\text { Menggunakan sarung tangan } \\
\text { saat bekerja }\end{array}$ & 27000 \\
\hline PA9 & $\begin{array}{l}\text { Mengatur ulang posisi } \\
\text { karyawan saat bekerja }\end{array}$ & 15840 \\
\hline PA10 & $\begin{array}{l}\text { Membuat partisi di area kerja } \\
\text { karyawan }\end{array}$ & 12000 \\
\hline PA11 & $\begin{array}{l}\text { Mengatur pergantian shift } \\
\text { karyawan }\end{array}$ & 9450 \\
\hline PA12 & $\begin{array}{l}\text { Menerapkan peraturan wajib } \\
\text { menggunakan masker bagi } \\
\text { pelanggan }\end{array}$ & 6600 \\
\hline PA13 & $\begin{array}{l}\text { Penyediaan fasilitas sanitasi } \\
\text { di depan toko }\end{array}$ & 3600 \\
\hline PA14 & $\begin{array}{l}\text { Pengecekan suhu tubuh } \\
\text { pelanggan yang akan masuk } \\
\text { ke toko }\end{array}$ & 3000 \\
\hline PA15 & $\begin{array}{l}\text { Membuat sekat/partisi pada } \\
\text { area kasir }\end{array}$ & 4800 \\
\hline PA16 & $\begin{array}{l}\text { Menyediakan pembayaran } \\
\text { dalam bentuk non-tunai }\end{array}$ & 3600 \\
\hline PA17 & $\begin{array}{l}\text { Membuat tanda pembatas di } \\
\text { lantai pada area yang sering } \\
\text { terjadi kerumunan }\end{array}$ & 4800 \\
\hline PA18 & $\begin{array}{l}\text { Membuat kuota maksimal } \\
\text { pelanggan yang masuk ke } \\
\text { dalam toko pada satu waktu }\end{array}$ & 3600 \\
\hline & $\begin{array}{l}\text { Melakukan sanitasi pada } \\
\text { benda-benda yang sering } \\
\text { disentuh secara berkala }\end{array}$ & 9675 \\
\hline
\end{tabular}

Dari hasil kajian, terdapat sembilan belas tindakan pengendalian untuk melakukan mitigasi risiko keamanan pangan di Boys Cake \& Bakery selama masa pandemi COVID-19. Semua tindakan pengendalian tersebut mengacu pada pedoman BPOM. Dari sembilan belas tindakan tersebut, dua tindakan mengacu pada poin sanitasi pangan, enam tindakan mengacu pada poin personel, tiga tindakan mengacu pada poin physical distancing, satu tindakan mengacu pada poin komunikasi, informasi dan edukasi serta tujuh tindakan mengacu pada poin distribusi dan ritel.

\section{KESIMPULAN}

a. Hasil identifikasi risiko menunjukkan bahwa pada proses bisnis Boys Cake \& Bakery terdapat 24 kejadian risiko yang ditemukan. Dari 24 kejadian risiko tersebut, teridentifikasi 32 penyebab risiko yang mungkin muncul mengakitbakan terjadinya risiko.

b. Berdasarkan prinsip pareto, didapatkan sepuluh penyebab risiko yang dominan yaitu penyebab risiko dengan kode A21, A23, A20, A22, A31, A19, A27, A26, A28, dan A29.

c. Didapatkan 19 tindakan pengendalian yang dirancang untuk melakukan penanganan risiko pada Boys Cake \& Bakery di masa pandemi Covid-19.

\section{UCAPAN TERIMA KASIH}

Ucapan terima kasih diberikan kepada Boys Cake \& Bakery yang telah memberikan fasilitas dalam menyelesaikan penelitian ini.

\section{DAFTAR PUSTAKA}

BPOM. (2019). Program Manajemen Risiko Keamanan Pangan di Industri Pangan. Jakarta: BPOM.

BPOM. (2020). Pedoman Produksi dan Distribusi Pangan Olahan Pada Masa Status Darurat Kesehatan Covid-19. Jakarta: BPOM.

BSN. (2018). Grand Desain Penerapan Manajemen Risiko. Jakarta: BSN.

Geraldin, L. H. (2007). Manajemen Risiko dan Aksi Mitigasi Untuk Menciptakan Rantai Pasok yang Robust. Jurnal Torsi.

Hariyadi, P. (2017). Kemanan Pangan: Prasyarat Dasar Pangan. Jakarta: BPOM.

Hariyadi, P. (2020). Industri Pangan Indonesia Perlu Pedoman Hadapi Wabah Covid-19. Food Review Indonesia, 18-19.

Hidaya, S. (2012). Analisa dan Mitigasi Risiko Rantai Pasok Pada PT. Crayfish Softshell Indonesia. Surabaya: ITS.

Kemenperin. (2020). PedomanSurat Edaran Menteri Perindustrian Nomor 7 Tahun 2020 Jakarta: Pemerintah RI.

Kemenkes. (2019). Peraturan Menteri Kesehatan Republik Indonesia Nomor 25 Tahun 2019. Jakarta: Pemerintah Rl. 
Kemenkes. (2020). Peraturan Menteri Kesehatan Republik Indonesia Nomor 9 Tahun 2020. Jakarta: Pemerintah RI.

Kemenkes. (2020, Juni 29). Tentang Novel Coronavirus. Jakarta: Kementerian Kesehatan Republik Indonesia. Retrieved from https://www.kemkes.go.id/ diakses pada 29 Juni 2020.

Lukman, A. S. (2020, April 30). Peran Standard dalam Upaya Mendukung Jaminan Mutu dan Keamanan Pangan dalam Masa Pandemi Covid-19.

Luthfiani, A. N. (2019). Analisis Pengukuran Dan Pengendalian Risiko Supply Chain Pada
Cv Ganep Surakarta Dengan Menggunakan Metode House Of Risk. Surakarta: UMS.

Presiden RI. (2020). Keputusan Presiden Republik Indonesia Nomor 12 Tahun 2020. Jakarta: Pemerintah RI.

Rahmatullah. (2016). Pengukuran Dan Pengelolaan Risiko Pada Supply Chain Ikm Intip Dengan Pendekatan Metode HOR. Surakarta:UMS.

Zazili, A. (2019). Urgensi Pengawasan Keamanan Pangan Berbasis Sistem Manajemen Risiko Bagi Perlindungan Konsumen. Jurnal Penelitian Hukum. 